NEWS FOR THE ASSOCIATION

Due to technical difficulties the ASN business meeting could not be held at the AAASS annual convention in Monterey, California in 1981. Therefore, it will be held during the AAASS convention in Washington, D.C. on October 15, 1982. The time and place will be announced in the Program of the convention. ASN Executive Members, Members at Large, as well as members of the Association are urged to be present at the meeting. The report of the executive officers and the election of the new Board of Executives will be on the agenda of the meeting.

ASN proposed two sessions for the 1982 convention:

(1) "Soviet Nationalities Studies in the United States: Progress, Problems, and Prospects."

(2) "Eastern Europe National Minorities, 1919-1980: Conflicts and Solutions."

ASN members are urged to attend these sessions which reflect the Association's interest in the areas of its main academic concern.

The Executive Board of the ASN appeals to the membership to support the Association's activities and its publications. Also, financial support in the form of life memberships and donations, which are tax deductible, are sought from our generous patrons. The initiative to place Nationalities Papers on standing order with your respective libraries offers still another means in making an effective ASN contribution to Western scholarship for years to come. 


\section{INFORMATION FOR CONTRIBUTORS}

Nationalities Papers welcomes manuscripts from members of the ASN and others specializing in subjects and areas of the Association's interest. All manuscripts should be submitted in duplicate, double-spaced and typed on one side of the page only. Footnotes should be typed double-spaced at the end of the paper. Cyrillic alphabets should be transliterated according to the Library of Congress system, without diacritical marks. Manuscripts should not exceed 30 pages in length (including notes). In all matters of style, the practice recommended by K. L. Turabian, A Manual for Writers, 4th ed., is normally followed. Book reviews should give complete bibliographic description. Unsolicited book reviews are not accepted.

Manuscripts will not be returned unless specifically requested and postage is provided. The policy of the Nationalities Papers is not to consider materials published elsewhere.

\section{THE SHEVCHENKO SCIENTIFIC SOCIETY OF THE U.S.}

\section{Publications available}

Ukraine: A Concise Encyclopedia. Edited by Volodymyr Kubijovych. 2 vols. $\$ 95.00$.

M. Stakhiv. Ukraine and Russia: An Outline of the History of Political and Military Relations (December 1917-April 1918). 215 pp. \$10.00.

M. Bohachevsky-Chomiak. The Spring of a Nation in Eastern Galicia in 1848. 132 pp. $\$ 5.00$.

N. Chirovsky, ed. On the Historical Beginnings of Eastern Slavic Europe. 223 pp. $\$ 10.00$.

Ivan Franko. The Master's Jests. Translated by Roman Tatchyn. 133 pp. $\$ 10.00$.

Illia Vytanovych. Istoriia ukrains'koho kooperatyvnoho rukhu (History of the Ukrainian Cooperative Movement). 624 pp. $\$ 20.00$.

Ukrains'ka knyha (The Ukrainian Book). A Ukrainian bibliographical quarterly. \$10.00 annually.

THE CATALOG LISTING 235 TITLES IS AVAILABLE FREE OF CHARGE UPON REQUEST.

SHEVCHENKO SCIENTIFIC SOCIETY, Inc. 302-304 West 13th Street

New York, N.Y. 10014 (Tel. (212) 929-7622) 